\title{
Critical role of ethics in clinical management and public health response to the West Africa Ebola epidemic
}

This article was published in the following Dove Press journal:

Risk Management and Healthcare Policy

12 May 2016

Number of times this article has been viewed

\author{
Morenike O Folayan ${ }^{1,2}$ \\ Bridget G Haire ${ }^{3}$ \\ Brandon Brown ${ }^{4}$ \\ 'Institute of Public Health, \\ ${ }^{2}$ Department of Child Dental Health, \\ Obafemi Awolowo University, Ile-Ife, \\ Nigeria; ${ }^{3}$ Kirby Institute for Infection \\ and Immunity in Society, University \\ of New South Wales, Sydney, NSW. \\ Australia; ${ }^{4}$ Center for Healthy \\ Communities, Department of \\ Social Medicine and Population \\ Health, University of California \\ Riverside School of Medicine, \\ Riverside, CA, USA
}

\begin{abstract}
The devastation caused by the Ebola virus disease (EVD) outbreak in West Africa has brought to the fore a number of important ethical debates about how best to respond to a health crisis. These debates include issues related to prevention and containment, management of the health care workforce, clinical care, and research design, all of which are situated within the overarching moral problem of severe transnational disadvantage, which has very real and specific impacts upon the ability of citizens of EVD-affected countries to respond to a disease outbreak. Ethical issues related to prevention and containment include the appropriateness and scope of quarantine and isolation within and outside affected countries. The possibility of infection in health care workers impelled consideration of whether there is an obligation to provide health services where personal protection equipment is inadequate, alongside the issue of whether the health care workforce should have special access to experimental treatment and care interventions under development. In clinical care, ethical issues include the standards of care owed to people who comply with quarantine and isolation restrictions. Ethical issues in research include appropriate study design related to experimental vaccines and treatment interventions, and the sharing of data and biospecimens between research groups. The compassionate use of experimental drugs intersects both with research ethics and clinical care. The role of developed countries also came under scrutiny, and we concluded that developed countries have an obligation to contribute to the containment of EVD infection by contributing to the strengthening of local health care systems and infrastructure in an effort to provide fair benefits to communities engaged in research, ensuring that affected countries have ready and affordable access to any therapeutic or preventative interventions developed, and supporting affected countries on their way to recovery from the impact of EVD on their social and economic lives.
\end{abstract}

Keywords: Ebola, ethics, global comparison

\section{Introduction}

The magnitude of the recent Ebola virus disease (EVD) outbreak in West Africa has been unprecedented in many ways. This is the first time an EVD outbreak has occurred in West Africa although EVD outbreaks in Africa have been documented since 1976. This outbreak is unique in its size, duration, and spatial extent. ${ }^{1}$ It has generated intense debates on appropriate international responses to infectious disease emergencies, the processes of researching new treatments and vaccines during an epidemic outbreak, and standards for prevention and care. These debates have also focused national and international attention on disparities in health care standards between developed and developing countries, on differing applications of ethical standards governing the right to health between developed and developing countries arising from these disparities,
Correspondence: Morenike O Folayan Department of Child Dental Health, Obafemi Awolowo University, Ile-lfe 22005, Nigeria

Email toyinukpong@yahoo.co.uk 
and the ethical responsibilities of various agencies in the current and future infectious disease outbreaks.

In this paper, we analyzed the ethical considerations that arose from the clinical management and public health responses to EVD outbreak in West Africa, identified the similarities and differences in the application of these ethical standards in developed and developing countries, and considered the implications of our findings for future global health emergency responses. Our analysis is based on a reflection of the social-ecological model widely used in health behavior research and practice to assess the multiple levels that influence a health issue. More specifically, this model is unique because it allows the researcher or practitioner to identify the individual, interpersonal, organizational, community, and public policy factors that contribute to a particular health issue or event so that health professionals and/or researchers may identify the best intervention or research methods. Therefore, we will detail the ethical issues that impact the Ebola epidemic from a social-ecological model analysis.

\section{The recent Ebola epidemic}

The West African EVD epidemic resulted in the death of five times as many people as every other known EVD outbreak combined. ${ }^{2}$ It is also the largest ever emergency operation in the 70 year history of the World Health Organization (WHO). ${ }^{3}$ Liberia, Sierra Leone, and Guinea bore the brunt of the epidemic, though cases were also reported in Nigeria, Mali, Senegal, the United States, and Spain. Only three infections occurred outside West Africa (two in the US and one in Spain). At the time of the EVD epidemic in West Africa, another EVD epidemic caused by an unrelated EVD strain occurred in the Democratic Republic of Congo in August 2014, with 66 cases and 49 deaths. This was contained, and the country has remained EVD free since November 2014. The West African region had been on the brink of being declared EVD-free several times but for instances of new case identification in Sierra Leone ${ }^{4}$ and Liberia. ${ }^{5}$ The region was finally declared EVD free on January 14, 2016. ${ }^{6}$ There are, however, potentials for multiple flare-ups in the region as some survivors could sexually transmit infection. ${ }^{7,8}$

The West Africa epidemic was different in many respects to past EVD epidemics. First, it is the largest and longest EVD outbreak in history, ${ }^{3}$ involving several developed and developing countries. Fears of cross-border transmission resulted in over 50 countries around the world issuing travel restrictions to and from EVD-affected countries. ${ }^{9}$ Second, the epidemic garnered international support, including significant investment in the research and development of vaccines ${ }^{10}$ and therapies ${ }^{11,12}$ for EVD infection, although the response was slow and arguably inadequate. ${ }^{13,14}$ Third, it stimulated debates at many international, regional, and national fora about compassionate access to experimental regimens for therapy during epidemics and alternative clinical trial designs to test the efficacy and effectiveness of vaccines and therapies. The debates resulted in guidelines being developed, ${ }^{15}$ and considerations for revised ethical guidance on clinical trial design and sharing of biospecimens and data. ${ }^{16}$ Actions are also being taken to institute structural measures for improved emergency response capacities around the world. ${ }^{3}$

One of the ethical debates was the overarching moral problem of severe transnational disadvantage, which has very real and specific impacts upon the ability of citizens in Liberia, Guinea, and Sierra Leone to proactively exercise their right to health under normal conditions, let alone when their countries were in the grip of an epidemic. ${ }^{17}$ Of note, Liberia had 51 doctors for its population of 4.3 million people. ${ }^{18}$ The drastically under-resourced health care structures and systems in these countries constitute moral problems in themselves and both heighten and complicate the other ethical issues that arose in relation to the epidemic. Accordingly, we reviewed the literature and discuss ethical considerations in the West African EVD outbreak from a perspective that is grounded in a critique of the social and structural elements that contributed to the deprivation of the individuals and communities that bore the brunt of the epidemic. These include ethical analysis of public health measures such as quarantine, isolation, protection of health care workers, and travel restrictions. We also analyzed the debates that had taken place regarding research ethics, including the conduct of research during public health emergencies, the ethics of randomization, standards of care both within and outside research studies, and the sharing of biospecimens and related data internationally. Finally we considered the ethical issues surrounding the topic of EVD survivors.

\section{Ethical challenges related to the EVD epidemic in West Africa}

Three months elapsed (from December 6, 2013 to March $10,2014)$ between the first death now attributed to the West African outbreak, and the first notification of national health authorities. By this time, there were clusters of infection in four districts. ${ }^{19}$ The recent histories of civil war, unstable government, and political violence in the affected countries negatively impacted the ability of the health systems to meet the care and containment demands of an exploding public 
health crisis. Also, the civil distrust of and misgivings toward the government, due to long years of neglect of health services and systems, slowed down the public response. ${ }^{18,20,21}$ At the time of the outbreak, many international donor agencies that had handled past emergency health problems were establishing fledgling transitional systems intended to reduce donor dependence in the region and were therefore not operating at maximum potential. ${ }^{22-25}$ Also, individuals had grown to depend on alternative health care providers in view of the dilapidated health care structures and systems. ${ }^{25}$

Thus, the initial calls by the government to take precautions against EVD infection were treated with levity. The disease was unknown in the region, and the public health messages stigmatized cherished traditional practices as "risky behaviors", arising from the logical clinical and epidemiological framings of contagion. ${ }^{26}$ For example, the cultural practice of burial rites, which were designed as a means of parting with the dead through a show of dignity and respect, were now labeled "bad", and people were requested to make immediate and extensive changes in their core practices and ways of relating and interacting to curb EVD spread. ${ }^{26}$ Also, the sudden urgent need for clean water for regular hand washing brought with it its own challenges as access to regular clean water was limited. ${ }^{27}$ Public myths and misconceptions soon grew from the government actions, with many believing that the government was merely interested in sourcing for new foreign aid for further personal enrichment. ${ }^{28}$

With increasing cases of EVD infection, poor standards of care in health facilities, ${ }^{29,30}$ high case fatality, ${ }^{31}$ and large numbers of people turned back from treatment centers, ${ }^{32}$ many individuals also had to become personally responsible for their individual care. Care of the sick at home became the backup for managing many cases, ${ }^{33,34}$ and in such situations, individuals had to learn to provide care for infected and affected loved ones while ensuring personal protection.

\section{Ethical debates about quarantine in Ebola affected regions}

Quarantine helps to contain new infections during an infectious disease outbreak. ${ }^{35}$ One of the criticisms of the initial outbreak response was that the quarantine was poorly managed. $\mathrm{Koch}^{35}$ and Barbisch et $\mathrm{al}^{36}$ argue that quarantine of whole communities could be ethically justified, particularly if the containment area included the entire area within which individuals from a community would usually travel. Koch ${ }^{35}$ describes this as a spatial focus for quarantine rather than one focused on a targeted population. It allows for better concentration on humanitarian medicine for the infected, as far greater concentration of resources would be available for a smaller pool of infected people. A call for "spatial" quarantine for EVD containment may be at odds with the "principle of least infringement", an ethical principle applied in public health contexts to curtail the use of liberty-restricting interventions to the least restrictive action required to meet a public health goal. But when the public health goal is containment of an infectious disease to meet the dual goals of enabling the best possible care for the sick within the quarantine zone, as well as to reduce the spread of infection, such a measure could be ethically justified. Restrictions should therefore be done in a way that is relevant, legitimate, and necessary, and stakeholders should be fully informed about the risks and benefits, especially as they affects their health, well-being, and personal liberty. ${ }^{37}$ Those quarantined should also not suffer unfair economic penalties. ${ }^{37}$

The tension between quarantine as a public health measure and individual rights to privacy, liberty, and freedom of movement is well recognized, and the need to strike a balance between the utilitarian aim of promoting public health, on the one hand, and libertarian aims of protecting privacy and freedom of movement on the other hand, have been widely discussed. ${ }^{37-39}$ There is a reasonable expectation that when people are asked to surrender their liberty through quarantine, there is a reciprocal obligation to provide adequate care for individuals who have complied. When such care is not forthcoming or when it is inadequate, it can be argued that the individual, who is legally required to report for quarantine, does not have a moral obligation to do so.

For a situation like the EVD epidemic where scientific uncertainty about the disease was pervasive, respect for the rights and dignity of affected persons required commitment to planning to address the associated challenges. ${ }^{38,39}$ The lack of consideration for the needs of the most affected individuals when quarantines were instituted during the EVD epidemic affected the success of quarantines measures to quickly contain the epidemic: ${ }^{3}$ the associated unmet basic needs and economic constraints resulting in the need for food were common reasons given for the breach when affected cities were "shut down", 35 thereby limiting the effectiveness of instituted quarantine.

\section{Ethical debates about quarantine in developed countries}

As part of the "fear" response to EVD in the USA, asymptomatic health care workers returning from West Africa were required to be quarantined for 21 days. ${ }^{9}$ This form of quarantine is similar to one proposed by American law 
professor Gostin ${ }^{39}$ who, in another infectious disease context, suggested that citizens may be forcefully excluded from returning to their home for a period of time when an infectious individual poses a risk to others on international conveyances. We consider, however, that the probable benefits of a restrictive measure for health care workers returning to their home country are not sufficient to justify any burden placed on individuals through the restriction of their liberty, taking into consideration any probability. ${ }^{40}$ Subsequently, the quarantine order for health care workers returning to their homeland from the EVD zone was deemed counterproductive and "morally wrong" by the President's Bioethics Commission. ${ }^{41}$ The action was also not evidence based, infringed the right to liberty of affected individuals, ${ }^{42}$ fueled stigma, ${ }^{43,44}$ and constituted a roadblock to the ongoing EVD response. ${ }^{45}$ It imposed barriers to the movement of health care workers to and from affected areas and impeded their ability to contribute their skills to the management of the public health emergency. ${ }^{45}$

\section{Ethical debates on isolation of sick persons}

Isolation of individuals sick with EVD during the period when they could transmit infection is an appropriate public health response. Confinement should, however, be in safe places, and isolated individuals should have access to adequate health care, food, clothing, and means of communication with families and friends. ${ }^{39}$ The appalling state of many isolation units ${ }^{46}$ and the poor treatment of infected persons in West Africa ${ }^{47}$ was a disincentive for anyone to self-report at EVD treatment units. Sick patients in West Africa may not be morally obliged to seek isolation, regardless of the law, knowing that isolation likely implies dying alone without family and friends. $\mathrm{WHO}^{3}$ noted this as one of its main challenges for EVD containment: people continued to stay at home and secretly bury their dead even when sufficient treatment beds and burial teams were available. Sick patients in developed countries will, however, be morally obliged to seek isolation, since optimal care will be provided in well-equipped care centers.

For a situation like the EVD outbreak where no curative medicine was available and where access to a reasonable standard of supportive care was the best that treatment facilities could offer, equitable distribution of such care is of great ethical importance, given the public health imperative for people to show up at treatment units. No preferential treatment should be offered on the basis of profession as a show of respect for the rights and dignity of infected persons.

\section{Ethical debates about travel restrictions}

Concerns about the potential for EVD to travel across borders resulted in travel restrictions in many countries, and screening for fever was recommended at the airports in Liberia, Guinea, and Sierra Leone and instituted in many airports worldwide. ${ }^{9}$ The possibility of Ebola being used for bioterrorism intensified concern about cross-border movement of people who may have been exposed to EVD.48

Instituting travel bans far from the Ebola epicenter, however, defies the public health ethics principle of least infringement, which recognizes the need to respect and protect individual and community needs, interests, rights, and liberties and to ensure that these are curtailed to the minimum degree required to curtail a public health threat. ${ }^{41}$ The international laws recognize the right to freedom of movement to leave and return to one's country of origin. ${ }^{49,50}$ While restricting travel of persons infected with EVD may seem intuitively right to contain the epidemic, such restriction would reduce the opportunity for medical evacuations, which was demonstrated to increase rates of survival. ${ }^{51}$ In addition, allowing travel in and out of Ebola-affected nations facilitated the movement of humanitarian workers and supportive materials for EVD prevention, care, and infection control.

\section{Ethical dilemmas that informed health care workers' response to the epidemic}

Health professionals of all kinds, from a village midwife to hospital doctors, featured in the transmission chains. ${ }^{52}$ The poor infrastructure and support systems for sick persons ${ }^{53}$ resulted in health care workers in some facilities being afraid to provide care ${ }^{54}$ - a reasonable fear, given the high number of infections affecting the health force. ${ }^{55}$ Yakubu et $\mathrm{al}^{56}$ recognized the fundamental issues that underscored health workers concerns and possible reluctance to offer services during the epidemic in West Africa and advocated that health care workers are under no obligation to provide medical care for patients with EVD when the government cannot provide them with required personal protective equipment and training to play their role safely and effectively.

For health professionals working outside the West African region, the risk of exposure was remote, but nonetheless did occur due to people with EVD either traveling while ill $^{57,58}$ or being medically evacuated..$^{57,59}$ Some of the health professionals who handled patients' care were not adequately trained to provide care for patients with EVD and were left vulnerable to infection. ${ }^{60}$ Health care workers in $\mathrm{USA}^{61}$ and Spain $^{62}$ acquired EVD while nursing patients. 
The infection of foreigners who traveled to the West African region resulted in considerable debate about which categories of health care workers are obliged to provide care and which are not, and whether there are particular medical procedures that should be barred for patients with EVD because of the risk posed. ${ }^{63,64}$ In addition, public concerns focused on the obligation of employers to ensure provision of adequate equipment for health care workers faced with the risk for EVD infection. Debate over the optimal design of protective equipment ${ }^{65}$ resulted in protocols recommending different levels of respiratory protection ${ }^{66}$ and detailed training on the use of personal protective equipment.

\section{EVD research ethics}

The EVD outbreak catalyzed a flurry of scientific activity to consider investigational compounds under development and to hasten their pathway into human trials. In 2014, the Ethics Advisory Committee to the WHO met and issued a statement that supported the use of unregistered interventions in the EVD epidemic. ${ }^{15}$ This gave credence both to EVD research efforts and to compassionate use of unproven agents. There were intense debates about the appropriate design and conduct of EVD vaccine and drug trials. Much of this debate centered on the ethics of randomization in the midst of an epidemic with high case fatality. ${ }^{67-71}$ Those in favor of randomized clinical trial argued that EVD clinical trials present a situation of genuine uncertainty, and therefore justified randomization to experimental treatment versus placebo. ${ }^{72-74}$ Also, drug registration for licensure would require data generated through randomized clinical trials. ${ }^{70,71}$ Those in favor of alternative trial designs ${ }^{67,68,75-78}$ noted that ethical standards guiding therapeutic research should be flexible enough to give the dying "a chance at rescue". ${ }^{78}$ Also, alternative research designs facilitated access of persons to experimental products to reduce the risk of fatality, especially with promising experimental products. ${ }^{67,78,79}$ The Ebola ca Suffit trial provided evidence on the suitability of an alternative vaccine trial design to generate evidence on the effectiveness of a vaccine. ${ }^{80}$

\section{Ethical dilemmas informing policy response to the epidemic}

Within a public health emergency, values defined by public health ethics - an overriding priority afforded to "greater good" considerations ${ }^{57,81}$ - should take precedence over individual concerns, according to ethicist Dawson.$^{82}$ Dawson was particularly concerned that the WHO Advisory Panel meeting held in September $2014^{83}$ focused on "individualistic" values
- the use of unregistered interventions for clinical care or prevention - rather than on the "old fashioned public health methods" such as quarantine, contact tracing, and social distancing. ${ }^{82}$ In response, Haire and Folayan ${ }^{79}$ argued that access to treatment, whether experimental or not, should not be separated from "public health ethics", given that community support for and compliance with public health containment measures requires some reciprocity. Also, some hope of an effective treatment, however remote, could assist individuals and communities in accepting otherwise unwelcome public health measures.

\section{Ethical considerations on the obligations to assist}

Some scholars argued that developed countries have an ethical obligation to support countries in the EVD zone. ${ }^{20}$ Countries in the EVD zone were in dire need of support to control an outbreak that was out of hand, and such support would be at minimal cost to the developed country. ${ }^{84,85}$ As sponsors of EVD therapeutic research, the developed countries had an ethical obligation to contribute to the containment of EVD infection by strengthening local health care systems and infrastructure in an effort to provide fair benefits to communities that are engaged in research. ${ }^{20}$ Also, recognizing that relationships with others will inevitably require mutuality and reciprocity implies that developed countries need to provide support for affected West African countries at their time of need. ${ }^{45}$ The strengthening of the health care systems to enhance EVD response and support current and future research should be considered a social response to the needs of developing countries by developed countries. ${ }^{20}$

\section{Ethical considerations on sharing of data and biospecimens for EVD response}

The collection of biospecimens is critically important for advancing research into treatment and preventative interventions and for improving understanding of the pathogenesis and genetic variation of EVD. ${ }^{86}$ As such, specimens must necessarily be collected during an outbreak and shared with other researchers working on developing treatment and vaccines long after the epidemic is over. This raises ethical issues about informed consent. While informed consent ought to be obtained before taking any specimen, caring for very ill people focused on survival in often suboptimal treatment units makes this difficult. Also, there are concerns about obtaining informed consent from minors who may not have parents or guardian present while quarantined, or the parents may have died as a result of the epidemic. In 
the case of deceased people, the USA regulations do not require consent before taking biospecimens. It is, however, recognized that deceased people may have had interests and values regarding the use of their specimens that should be respected. ${ }^{86}$ Similarly, the USA does not require consent for use of deidentified specimens, but the ethical concerns still hold, since genomic research, where data cannot truly be deidentified given that every human genome is unique, is possible. ${ }^{48}$ Jecker et $\mathrm{al}^{87}$ therefore identified the need for additional guidance on the challenges of obtaining informed consent for collecting and sharing biospecimens in the context of a public health emergency.

Concerns about sharing of benefits accruing from biospecimen and data sharing has been raised in view of the competitive and privatized nature of EVD research and drug development and the reality that most of the EVD-related research would need to be conducted in high-tech Biological Safety Level-4 laboratories found more readily in developed countries. ${ }^{88}$ Lessons from the 2009 influenza A (H1N1) vaccine development process, and how financially empowered economies bought up manufactured vaccines, are recent examples that cause concern about future access to EVD treatments and vaccine. ${ }^{89}$ It is proposed that before data sharing of any kind occurs, there should be clear and equitable benefit sharing arrangements created through legally enforceable contractual obligations to ensure that people in EVD-affected countries have ready and affordable access to any therapeutic or preventative interventions that result from research. This proposal is in line with the principles enshrined in the 2011 Pandemic Influenza Preparedness Framework ${ }^{90}$ and respects the principle of reciprocity. ${ }^{91}$

\section{EVD survivors}

For EVD survivors, a different set of dynamics come into play. Many survivors are left impoverished. EVD infection means that personal property is confiscated with little or no support to replace these assets upon recovery. ${ }^{92}$ Misconception about the likelihood of contagion of EVD post-recovery gives rise to stigma and discrimination resulting in many survivors not being able to retain their jobs or get new jobs. ${ }^{93}$

The high demand for the blood of EVD survivors for therapeutic purposes meant that selling of blood, even in the black market, was a good means of income generation for many survivors. ${ }^{94}$ The sale of blood and blood in exchange for income by the poor is a well-recognized practice in many countries, including those affected by the Ebola outbreak..$^{95}$ This consideration posed an ethical dilemma for the Global Emerging Pathogens Consortium when considering how to compensate blood donors for their research on use of EVD survivors' blood for EVD therapy research, recognizing that EVD survivors have a right to the income they make from sale of their blood. ${ }^{96}$

\section{Discussion and recommendations Socioeconomic impact of the epidemic}

The EVD epidemic resulted in extensive loss of life and property. Altogether, 26,350 persons were managed for EVD infection and 11,315 lives were lost. ${ }^{97}$ The extensive casualty and the embargoes on travels and movements during the outbreak also affected trade and agriculture, resulting in food insecurity in affected countries. ${ }^{98}$ The impact of the epidemic on education remains unmeasured, yet the fact that schooling was extensively disrupted would have short-, medium-, and long-term consequences at the individual, family, and community/national level. Extensive donor investment in the EVD response also has implications for funding of other research in the region as research funds were moved away from other disease areas to address the EVD emergency response needs. ${ }^{99}$ The instituted infection control measures also affected social interactions, although the scope of impact of EVD epidemic on the social dynamic of affected countries remains largely unknown and would be difficult to measure because pre-epidemic data are rarely available due to the unpredictable nature of disease outbreaks. However, it is known that infectious diseases have severe impact on biodiversity. ${ }^{100-102}$

The WHO's report on lessons learned from the 2014 EVD outbreak in West Africa $^{3}$ identified four big lessons all related to the structural interventions provided during the epidemic. The report failed to recognize the immense changes in the dynamics of life and livelihood of affected individuals, communities, and the country and the need to support affected countries on their way back from recovering from the social, environmental, cultural, and economic tolls of the epidemic. Such support would involve long-term commitment from international partners and donors. Unfortunately, the outcomes of such long-term support are difficult to measure. Yet, the people in West Africa impacted by EVD outbreak need such long-term support.

\section{Ethical obligation for EVD response at the individual level}

At the individual level, support is needed to help survivors resume normal lives and to address challenges such as emotional distress, health issues, loss of possessions, and difficulty regaining their livelihoods. ${ }^{103}$ Many EVD survivors 
face stigma, rejection, loss of jobs, ${ }^{104}$ and have to deal with posttraumatic stress disorders and health challenges associated with EVD. ${ }^{105,106}$

If affected countries organize their EVD surveillance systems in line with WHO requirements, ${ }^{3}$ it will be possible to organize the provision of support for survivors in need. However, surveillance systems as an epidemiological measure and a potential tool for intervention come with ethical challenges. First, it limits privacy as names of persons with EVD diseases will need to be reported. The use of namebased surveillance for HIV infection ${ }^{107}$ set the precedent for this public health measure. Such surveillance systems must however, be less intrusive. Affected communities need to be consulted on its importance, design and use, and the data must be used for legitimate purpose ${ }^{39}$ only, such as providing relief materials for interested individuals, as we have identified.

While confidential handling of data may not be a challenge in developed countries, this will likely be so for countries in the EVD zone, which have poorly developed health systems in general and surveillance systems in particular. ${ }^{108}$ This once again highlights the need for support to build the health systems in affected countries not just to be able to respond to the EVD epidemic but also respond appropriately to the management of infectious diseases in general. The absence of basic essential elements of public health is a recognized vector for EVD in affected countries. ${ }^{28,38}$ The call to strengthen health care systems in EVD-affected countries is an ethical and moral call.

\section{Ethical obligation for EVD response at the community level}

Effective EVD responses require extensive consultations and discussions with communities on appropriate measures of and support for instituted mechanisms to respond to the epidemic. The privacy-limiting nature of name-reporting associated with the operations of surveillance systems to monitor EVD requires that the public be educated about this measure and consulted on how best to undertake contact tracing. EVD survivors should also be consulted about how best to institute surveillance and contact tracing systems that reduce the risk for stigma. ${ }^{39}$

Social interventions at the community level include galvanizing support for members of the extended families who have adopted children orphaned by EVD. ${ }^{109}$ The possibility of supporting prompt adoption of orphaned children by qualified persons should also be explored. International support programs or projects should not seek to subsume these community practices of orphaned and vulnerable chil- dren's support with attractive alternatives. Rather, safe local practices of child care should be promoted. ${ }^{110}$

\section{Ethical obligation for EVD response at the country level}

At the country level, it is the ethical obligation of governments and appropriate authorities to ensure that hospitals maintain resources and adequate health care professionals to isolate and treat new patients with EVD. With depleted numbers of experienced health care workers in EVD-affected countries resulting from the high case fatality rate (as high as 59\%), ${ }^{111}$ affected countries will need regional and international support to augment health care delivery for citizens beyond providing support for those infected with EVD. The global community needs to continue to support medical personnel to travel to affected countries to help provide medical care for the short and medium term while the country makes effort to train more medical staff. There have been such past practices between national governments through North-South Collaborations and South-South Collaborations. ${ }^{112}$

Public policies on management and control of epidemiccausing infectious diseases in general, and EVD management and control specifically, need to be developed. For example, in the wake of the EVD outbreak in Nigeria, the national research ethics code was revised to allow for country access and use of experimental drugs on compassionate grounds for the management of EVD. The absence of this policy was a disincentive for the use of experimental drugs for Dr Sheik Humarr Khan in Sierra Leone. ${ }^{113}$ Public health policies in developing countries would also need to be revised to address the obligations of health care personnel to work in the time of an infectious disease outbreak. Policies that can guide the scientific and ethical conduct of research at the time of a national emergency would also be helpful and a welcome development. Policies on isolation of infected persons and quarantine of affected persons need to be based on robust legal and ethical justification. For EVD, where the probability of transmission and severity of harm justifies the need to restrict movements of people for public health purposes, consultation and communication with affected communities on "why" and "how" to implement measures is an ethical imperative. The options for practicing quarantine and isolation should not create divides between social classes and result in unjust treatment of the poor, such as creating food insecurity. ${ }^{38,39}$ Resources should also be committed to providing support for those who lose income through isolation and quarantine, as equity requires that those who 
forgo their freedom for the public good through quarantine and isolation should be compensated.$^{39} \mathrm{~A}$ broad public debate in each country is, however, required on how best to achieve equity. The outcome of the debate should inform policy and guidelines development.

\section{Ethical obligation for EVD response at the global level}

While travel advice and warnings about EVD-affected countries are welcome and appropriate global EVD public health responses, travel bans are not an effective response, but rather have significant negative consequences. Global solidarity for responding to a regional crisis can make significant difference to a health crisis at the individual, community, and national levels, as lessons from the field of HIV studies have demonstrated. The success of the US response to global HIV epidemics through its PEPFAR (President's Emergency Plan for AIDS Relief) program is a testimony to this. ${ }^{113} \mathrm{US}$ funding for the global HIV response is less than $1 \%$ of the annual budget. ${ }^{114}$ Yet, this minor budgetary allocation has had tremendous impact on the epidemic in developing countries. The same could be done for EVD-affected countries in West Africa.

As we go into the future, one of the ethical responsibilities of the global community is ensuring prompt unconditional access of low-income countries to developed therapies for EVD management. EVD outbreaks could still occur in the future. In view of the health and social development challenges of countries affected by EVD, the focus of the EVD response in West Africa should be one that combines genuine respect for the dignity of people with the idea of human development. ${ }^{115}$ This, therefore, requires that the global community should plan ahead for future outbreaks. While current EVD therapeutics are being developed by pharmaceutical companies and researchers in the North, plans need to be instituted for future access of these therapies by affected communities in the South. The WHO and appropriate entities like Global Alliance for Vaccines and Immunization need to start discussing modalities for future access to developed therapeutics ahead of product licensure and future outbreaks.

\section{Conclusion}

A global response to the EVD epidemic in West Africa is an ethical requirement of national, regional, and international governments in view of globalization and the diminishing relevance of national boundaries. The EVD outbreak dem- onstrated the magnitude of what can be achieved within a short time with global solidarity. We live in a time of fluid borders brought on by ease of travel, technological innovations, and an aggressive global media. This denies us the intellectual luxury of viewing global issues such as HIV infection, global warming, and, now, EVD from the narrow lens of a domestic crisis. It is a global crisis with impact at the individual, community, national, and international levels associated with ethical responsibilities for individuals, collectives, governments, and donor agencies.

\section{Disclosure}

The authors report no conflicts of interest in this work

\section{References}

1. Alexander KA, Sanderson CE, Marathe M, et al. What factors might have led to the emergence of Ebola in West Africa? PLoS Negl Trop Dis. 2015;9(6):e0003652.

2. BBC News. Ebola: mapping the outbreak. January 14, 2016. Available from: http://www.bbc.com/news/world-africa-28755033. Accessed January 24, 2016.

3. World Health Organisation. Ebola response: what needs to happen in 2015. January 2015. Available from: http://www.who.int/csr/disease/ ebola/one-year-report/response-in-2015/en/.Accessed January 24, 2016.

4. World Health Organisation. New Ebola cases in Sierra Leone. WHO continues to stress risk of more flare-up. January 15, 2016. Available from: http://who.int/mediacentre/news/statements/2016/new-ebolacase/en/. Accessed March 9, 2016.

5. Sierra Leone has 2nd Ebola case after epidemic believed over. THE BIG STORY. Available from: http://bigstory.ap.org/article/c2572197 0b224305a5e65da616226767/sierra-leone-has-2ndebola-case-afterepidemic-thought-over. Accessed January 24, 2016.

6. World Health Organisation. Latest Ebola outbreak over in Liberia; West Africa is at zero, but new flare-ups are likely to occur. January 15, 2016. Available from: http://www.who.int/mediacentre/news/ releases/2016/ebola-zero-liberia/en/. Accessed March 9, 2016.

7. Mate SE, Kugelman JR, Nyenswah TG, et al. Molecular evidence of sexual transmission of Ebola virus. N Engl J Med. 2015;373(25): 2448-2454.

8. Deen GF, Knust B, Broutet N, et al. Ebola RNA persistence in semen of Ebola virus disease survivors - preliminary report. $N$ Engl $J$ Med. Epub October 14, 2015.

9. Folayan MO, Brown B. Ebola and the limited effectiveness of travel restrictions. Disaster Med Public Health Prep. 2015;9(1):92.

10. Folayan MO, Yakubu A, Haire B, Peterson K. Ebola vaccine development plan: concerns and proposed measures. BMC Med Ethics. 2016;17:10.

11. van Griensven J, Edwards T, de Lamballerie X, et al. Evaluation of convalescent plasma for Ebola virus disease in Guinea. $N$ Engl J Med. 2016;374(1):33-42.

12. Medecins Sans Frontieres. Preliminary results of the JIKI clinical trial to test the efficacy of favipiravir in reducing mortality in individuals infected by Ebola virus in Guinea. February 24, 2015. Available from: http://www.msf.org/article/preliminary-results-jiki-clinicaltrial-testefficacy-favipiravir-reducing-mortality. Accessed January 23, 2016.

13. Ap T. Ebola crisis: WHO slammed by Harvard-convened panel over slow response. CNN. November 23, 2015. Available from: http:// edition.cnn.com/2015/11/23/africa/ebola-lancet-report/. Accessed January 27, 2016. 
14. Roland D. Experts criticize World Health Organization's 'slow' Ebola outbreak response. The Wall Street Journal. May 12, 2015. Available from: http://www.wsj.com/articles/experts-criticize-world-healthorganizations-slow-ebola-outbreak-response-1431344306. Accessed January 27, 2016.

15. World Health Organisation. Ethical considerations for use of unregistered interventions for Ebola virus disease (EVD). Summary of the panel discussion. August 12, 2014. Available from: http://www.who. int/mediacentre/news/statements/2014/ebola-ethical-review-summary/ en/. Accessed January 27, 2016.

16. Presidential Commission for the Study of Bioethics Issues. Privacy in Ethics and Ebola: Public Health Planning and Response. December 9, 2015. Available from: http://bioethics.gov/sites/default/files/ Privacy\%20-\%20Ethics\%20and\%20Ebola\%20-FINAL.pdf. Accessed January 27, 2016.

17. Kamradt A, Scott SH, Clare Wenham C, Smith F III. Saving Lives: The Civil-Military Response to the 2014 Ebola Outbreak in West Africa. NSW, Australia: The University of Sydney; 2015.

18. Boozary AS, Farmer PE, Jha AK. The Ebola outbreak, fragile health systems, and quality as a cure. JAMA. 2014;312(18):1859-1860.

19. Baize S, Pannetier D, Oestereich L, et al. Emergence of Zaire Ebola virus disease in Guinea. N Engl J Med. 2014;371(15):1418-1425.

20. Rid A, Emanuel EJ. Why should high-income countries help combat Ebola? JAMA. 2014;312(13):1297-1298

21. Fauci AS. Ebola - underscoring the global disparities in health care resources. N Engl J Med. 2014;371(12):1084-1086.

22. UNDP. Human Development Report. The Rise of the South: Human Progress in a Diverse World. New York, NY: UNDP; 2013. Available from: http://hdr.undp.org/en/2013-report. Accessed January 23, 2016.

23. Abramowitz SA. How the Liberian health sector became a vector for Ebola. Hot Spots, Cultural Anthropology website. October 7, 2014. Available from: http://www.culanth.org/fieldsights/598-how-theliberian-health-sector-became-a-vector-for-ebola. Accessed January 23, 2016.

24. Schroven A. Ebola in Guinea: revealing the state of the state. Hot Spots, Cultural Anthropology website. October 7, 2014. Available from: http:// www.culanth.org/fieldsights/587-ebola-in-guinea-revealing-the-stateof-the-state2014. Accessed January 23, 2016.

25. Abdullahi AA. Trends and challenges of traditional medicine in Africa. Afr J Tradit Complement Altern Med. 2011;8(5 Suppl):115-123.

26. Anoko JN. Communication with rebellious communities during an outbreak of Ebola virus disease in Guinea: an anthropological approach. Available from: http://www.ebola-anthropology.net/case_studies/ communication-with-rebellious-communities-during-an-outbreakof-ebola-virus-disease-in-guinea-an-anthropological-approach/. Accessed January 24, 2016.

27. United Nations Department of Economic and Social Affairs. International decade for action: water for life 2005 to 2015. Available from: http://www.un.org/waterforlifedecade/africa.shtml. Accessed January 27, 2016.

28. Folayan MO, Haire B. History, culture and social norms: implications for Ebola drug and vaccine clinical trials. In: Evans NG, Smith TC, Majumder MS, editors. Ebola's Message: Public Health and Medicine in the Twenty-First Century. Cambridge, MA: MIT Press; 2016.

29. Cleveland EC, Dahn BT, Lincoln TM, Safer M, Podesta M, Bradley E. Introducing health facility accreditation in Liberia. Glob Public Health. 2011;6(3):271-282.

30. Amnesty International. Out of reach: the cost of maternal health in Sierra Leone. 2009. Available from: https://www.amnestyusa.org/sites/ default/files/pdfs/outofreach.pdf. Accessed January 24, 2016.

31. Dixon MG, Schafer IJ; Centers for Disease Control and Prevention (CDC). Ebola viral disease outbreak - West Africa, 2014. Morb Mortal Wkly Rep. 2014;63(25):548-551.
32. Trvobic P. I had to turn people away from an Ebola treatment centre. It's desperate work. The Guardian. September 11, 2014. Available from: http://www.theguardian.com/commentisfree/2014/sep/11/ebolatreatment-centre-liberia. Accessed January 24, 2016.

33. Sifferlin A. This is how Ebola patients are equipping their homes. TIME. October 9, 2014. Available from: http://time.com/3481394/ equipping-homes-to-treat-ebola-patients/. Accessed January 24, 2016.

34. Söderström J. Ebola and the ex-combatant community. Fieldsights - Hot Spots, Cultural Anthropology Online. October 7, 2014. Available from: http://www.culanth.org/fieldsights/601-ebola-and-the-excombatant-community. Accessed January 24, 2016.

35. Koch T. Ebola, quarantine, and the scale of ethics. Disaster Med Public Health Prep. Epub October 9, 2015.

36. Barbisch D, Koenig KL, Shih, FY. Is there a case for quarantine? Perspectives from SARS to Ebola. Disaster Med Public Health Prep. 2015;9(5):547-553.

37. Singer PA, Benatar SR, Bernstein M, et al. Ethics and SARS: lessons from Toronto. BMJ. 2003;327:1342-1344.

38. Selgelid MJ. Ethics and infectious disease. Bioethics. 2005;19(3): 272-289.

39. Gostin LO, Bayer R, Fairchild AL. Ethical and legal challenges posed by severe acute respiratory syndrome: implications for the control of severe infectious disease threats. JAMA. 2003;290(24):3229-3237.

40. Boseley S. US quarantine for Ebola health workers 'morally wrong'. The Guardian. February 26, 2015. Available from: http://www.theguardian.com/world/2015/feb/26/us-quarantine-ebola-health-workersmorally-wrong-bioethics-commission. Accessed March 9, 2016.

41. Presidential Commission for the study of Bioethics Issues. Ethics and Ebola: Public Health Planning and Response. Washington, DC: Presidential Commission for the study of Bioethics Issues; 2015. Available from: http://bioethics.gov/sites/default/files/Ethics-andEbola_PCSBI_508.pdf. Accessed January 27, 2016.

42. Rothstein MA. The moral challenge of Ebola. Am J Public Health. 2015;105(1):6-8.

43. CBS News. Ebola fear causes stigma against West Africans in U.S October 31, 2014. Available from: http://www.cbsnews.com/news/ ebola-fear-causes-stigma-against-west-africans-in-u-s/. Accessed January 1, 2016.

44. McCarthy M. US nurse says she will fight Ebola quarantine. BMJ. 2014;349:g6555.

45. Drazen JM, Campion EW, Rubin EJ, Morrissey S, Baden LR. Ebola in West Africa at one year - from ignorance to fear to roadblocks. N Engl J Med. 2015;372(6):563-564.

46. Nossiter A. A hospital from hell, in a city swamped by Ebola. The New York Times. October 1, 2014.

47. Igonoh A. Ebola: 'I kept repeating to myself: I am a survivor. I am a survivor'. The Guardian. November 14, 2014. Available from: http:// www.theguardian.com/world/2014/nov/14/-sp-ebola-survivor-nigeriadoctor-patrick-sawyer. Accessed March 6, 2016.

48. Polesky A, Bhatia G. Ebola hemorrhagic fever in the era of bioterrorism. Semin Respir Infect. 2003;18:206-215.

49. International Covenant on Civil and Political Rights. New York, NY: United Nations; 1999: article 12, Section 1.

50. International Covenant on Civil and Political Rights. New York, NY: United Nations; 1999: article 12, Sections 2 and 4.

51. Uyeiki TM, Mehta A, Davey RT, et al. Clinical management of Ebola virus disease in the United States and Europe. $N$ Engl $J$ Med. 2016;374:636-646.

52. WHO Ebola Response Team. Ebola virus disease in West Africa - the first 9 months of the epidemic and forward projections. N Engl J Med. 2014;371:1481-1495.

53. Sack K, Fink S, Belluck P, Nossiter A. How Ebola roared back. The New York Times. December 29, 2014. Available from: http://www. nytimes.com/2014/12/30/health/how-ebola-roared-back.html?_r=0. Accessed December 30, 2014. 
54. BBC News. Two US Ebola nurses free of virus. October 25, 2014. Available from: http://www.bbc.co.uk/news/world-us-canada-29749283. Accessed January 23, 2016.

55. Kinsman J. A time of fear: local, national, and international responses to a large Ebola outbreak in Uganda. Global Health. 2012;8:15.

56. Yakubu A, Folayan MO, Peterson K, Brown B. Ebola virus outbreak in Western Africa and the ethical obligation to provide care. $J$ Med Ethics. Epub September 9, 2014.

57. Cass C. Anxiety rising in U.S., but expert says Ebola outbreak 'extraordinarily unlikely.' Associated Press. October 5, 2015. Available from: http://www.pbs.org/newshour/rundown/anxiety-rising-us-expertsays-ebola-outbreak-extraordinarily-unlikely/. Accessed January 27, 2016.

58. McCarty CL, Basler C, Karwowski M, et al. Response to importation of a case of Ebola virus disease: Ohio, October 2014. Morb Mortal Wkly Rep. 2014;63(46):1089-1091.

59. Chevalier MS, Chung W, Smith J, et al. Ebola virus disease cluster in the United States: Dallas County, Texas, 2014. Morb Mortal Wkly Rep. 2014;63(46):1087-1088.

60. Shoichet CE, Capelouto S, Yan H. Ebola outbreak: are health care workers prepared, protected? $C N N$. October 14, 2014. Available from: http://edition.cnn.com/2014/10/13/health/ebola-crisis/. Accessed January 27,2016

61. McCarthy M. Texas healthcare worker is diagnosed with Ebola. BMJ. 2014;349:g6200.

62. Gulland A. Spanish authorities investigate how nurse contracted Ebola. BMJ. 2014;349:g6120.

63. Frader J, Friedman Ross L. Responding to Ebola: health professionals' obligations to provide care. Bioethics Forum. November 7, 2014. Available from: http://www.thehastingscenter.org/Bioethicsforum/ Post.aspx?id=7168\&amp; blogid=140\&terms=Ebola+obligation + an d+\%23filename+*.html. Accessed January 26, 2016.

64. Edenson P. Don't categorically refuse CPR to Ebola patients. Bioethics Forum. January 15, 2015. Available from: http://www.thehastingscenter.org/Bioethicsforum/Post.aspx?id=7260\&amp; blogid=140\&terms= ebola+and+\%23filename+*.html. Accessed January 26, 2016.

65. Bieubien J. Dreaming up a safer, cooler PPE for Ebola fighters. Global Health. January 4, 2015. Available from: http://www.npr. org/2014/12/17/371413804/dreaming-up-a-safer-cooler-ppe-forebola-fighters. Accessed January 23, 2016.

66. MacIntyre CR, Chughtai AA, Seale H, Richards GA, Davidson PM. Respiratory protection for healthcare workers treating Ebola virus disease (EVD): are facemasks sufficient to meet occupational health and safety obligations? Int J Nurs Stud. 2014;51(11):1421-1426.

67. Adebamowo C, Bah-Sow O, Binka F, et al. Randomised controlled trials for Ebola: practical and ethical issues. Lancet. 2014;384(9952): 1423-1424.

68. Caplan AL, Plunkett C, Levin B. Selecting the right tool for the job. Am J Bioeth. 2015;15(4):4-10.

69. Kanapathipillai R, Restrepo AMH, Fast P, et al. Ebola vaccine - an urgent international priority. N Engl J Med. 2014;371(24):2249-2251.

70. Rid A, Emanuel EJ. Ethical considerations of experimental interventions in the Ebola outbreak. Lancet. 2014;384:1896-1899.

71. Dawson L. Not all RCTs are created equal: lessons from early AIDS trials. Am J Bioeth. 2015;15(4):45-47.

72. Goodman JL. Studying "secret serums" - toward safe, effective Ebola treatments. N Engl J Med. 2014;371(12):1086-1089.

73. Joffe S. Evaluating novel therapies during the Ebola epidemic. JAMA. 2014;312(13):1299-1300.

74. Cox E, Borio L, Temple R. Evaluating Ebola therapies - the case for RCTs. N Engl J Med. 2014;371(25):2350-2351.

75. Cooper, Ben S, Panngum W, et al. Evaluating clinical trial designs for investigational treatments of Ebola virus disease. PLoS Med. 2015;12(4):e1001815.

76. Cohen J, Kupferschmidt K. Ebola vaccine trials raise ethical issues. Science. 2014;346(6207):289-290.

77. Edwards SJ. Ethics of clinical science in a public health emergency: drug discovery at the bedside. Am J Bioeth. 2013;13(9):3-14.
78. Caplan AL. Morality in the time of Ebola. Lancet. 2015;385(9971): e16-e17.

79. Haire BG, Folayan MO. Ebola: what it teaches us about medical ethics. A response to Angus Dawson. J Med Ethics. 2016;42(1):59-60.

80. Henao-Restrepo AM, Longini IM, Egger M, et al. Efficacy and effectiveness of an rVSV-vectored vaccine expressing Ebola surface glycoprotein: interim results from the Guinea ring vaccination clusterrandomised trial. Lancet. 2015;386(9996):857-866.

81. Schwartz L, Hunt M, Sinding C, et al. Models for humanitarian health care ethics. Public Health Ethics. 2012;5(1):81-90.

82. Dawson AJ. Ebola: what it tells us about medical ethics. J Med Ethics. 2015;41(1):107-110.

83. World Health Organisation. Consultation on potential Ebola therapies and vaccines. Geneva, Switzerland. September 4-5, 2014. Available from: http://www.who.int/mediacentre/events/meetings/2014/ebolainterventions/en/. Accessed January 27, 2016.

84. Singer P. Famine, affluence and morality. Philos Public Aff. 1972;1(3): 229-243.

85. Caney S. Justice Beyond Borders: A Global Political Theory. New York, NY: Oxford University Press; 2005.

86. McGuire AL, Majumder MA, Halpern SD, et al. Taking DNA from the dead. Nat Rev Genet. 2010;11(5):318.

87. Jecker NS, Dudzinski DM, Diekema DS, Tonelli M. Ebola virus disease: ethics and emergency medical response policy. Chest. 2015;148(3):794-800.

88. Tindana P, Molyneux CS, Bull S, Parker M. Ethical issues in the export, storage, and reuse of human biological samples in biomedical research: perspectives of key stakeholders in Ghana and Kenya. BMC Med Ethics. 2014;15:76.

89. Fidler DP. Negotiating equitable access to influenza vaccines: global health diplomacy and the controversies surrounding avian influenza H5N1 and pandemic influenza H1N1. PLoS Med. 2010;7(5):e1000247.

90. World Health Organisation. Pandemic Influenza Preparedness Framework for the Sharing of Influenza Viruses and Access to Vaccines and Other Benefits. Geneva, |Switzerland: WHO; 2011. Available from: http://www.who.int/influenza/resources/pip_framework/en/.Accessed January 27, 2016.

91. Mascalzoni D, Dove ES, Rubinstein Y, et al. International Charter of principles for sharing bio-specimens and data. Eur J Hum Genet. 2015;23(6):721-728.

92. Gibbs JL. Property insurance may mitigate Ebola-related losses. Law360. November 3, 2014. Available from: http://www.law360. com/articles/592335/property-insurance-may-mitigate-ebola-relatedlosses. Accessed January 27, 2016.

93. Heyden EC. Ebola survivors fight prejudice. Nature. December 18, 2014. Available from: http://www.nature.com/news/ebola-survivorsfight-prejudice-1.16561. Accessed January 27, 2016.

94. Folayan MO, Brandon B, Yakubu A. Black market therapies for Ebola management: a potential for future epidemics. Glob Health Action. 2014;7:26356.

95. Edin K, Shaefer HL. Blood plasma, sweat, and tears. The Atlantic. September 1, 2015. Available from: http:/www.theatlantic.com/business/ archive/2015/09/poor-sell-blood/403012/. Accessed January 1, 2015.

96. Kombe F, Folayan M, Ambe J, Igonoh A, Abayomi A; GET members. Holding the bull by the horns: ethical consideration in designing multiple clinical trials and research protocols in the context of a dangerous pathogen outbreak. Soc Sci Med. Epub November 30, 2015.

97. World Health Organisation. Ebola response roadmap situation report. December 16, 2015. Available from: http://www.who.int/csr/disease/ ebola/situation-reports/en/. Accessed January 23, 2016.

98. World Food Programme. Guinea, Liberia and Sierra Leone - food insecurity on the rise as Ebola abates. June 2015. Available from: http:// documents.wfp.org/stellent/groups/public/documents/ena/wfp275534. pdf. Accessed January 23, 2016.

99. Vaccine News. Increased Ebola funding contributes to declines in other disease research. December 4, 2015. Available from: http://vaccinenewsdaily.com/stories/510651088-increased-ebola-funding-contributesto-declines-in-other-disease-research. Accessed January 27, 2016. 
100. Genton C, Cristescu R, Gatti S, et al. Recovery potential of a western lowland gorilla population following a major Ebola outbreak: results from a ten year study. PLoS One. 2012;7(5):e37106.

101. Genton C, Pierre A, Cristescu R, et al. How Ebola impacts social dynamics in gorillas: a multistate modelling approach. J Anim Ecol. 2014;84(1):166-176.

102. McCallum H, Dobson A. Detecting disease and parasite threats to endangered species and ecosystems. Trends Ecol Evol. 1995;10:190-194.

103. Lee-Kwan SH, DeLuca N, Adams M, et al. Support services for survivors of Ebola virus disease - Sierra Leone, 2014. Morb Mortal Wkly Rep. 2014;63(50):1205-1206.

104. Davytan, Brown B, Folayan MO. Addressing Ebola-related stigma: lessons learned from HIV/AIDS. Glob Health Action. 2014;7:26058

105. Hugo M, Declerck H, Fitzpatrick G, et al. Post-traumatic stress reactions in Ebola virus disease survivors in Sierra Leone. Emerg Med (Los Angel). 2015;5:285.

106. Fallah M. One year later: a cohort study of survivors of Ebola virus infection in Liberia (PREVAIL III). Abstract presented at: The 2016 Conference on Retroviruses and Opportunistic Infection, March 23, 2016, Boston, MA.

107. Gostin LO, Ward JW, Baker AC. National HIV case reporting for the United States; a defining moment in the history of the epidemic. N Engl J Med. 1997;337:1162-1167.

108. Tambo E, Ugwu E, Ngogang J. Need of surveillance response systems to combat Ebola outbreaks and other emerging infectious diseases in African countries. Infect Dis Poverty. 2014;3(1):1-8.
109. Focus 1000. Study on public knowledge, attitudes, and practices related to Ebola virus disease prevention and medical care in Sierra Leone. Available from: http://focus1000.org/images/KAP\%20Summary_Sept302014.pdf. Accessed January 23, 2016.

110. Street Child. Ebola orphan report. April 2015. Available from: http:// www.street-child.co.uk/ebola-orphan-report/. Accessed January 23, 2016

111. Satalkar P, Elger BE, Shaw DM. Prioritising healthcare workers for Ebola treatment: treating those at greatest risk to confer greatest benefit. Devel World Bioeth. 2015;15(2):59-67.

112. Rosseel P, De Corte E, Blommaert J, Verniers E. Approaches to North-South, South-South and North-South-South Collaboration: policy document. Available from: http://www.mcr-bvba.be/documents/ approaches-tonorth-south-s-s-and-n-s-s-collaboration-a-policydocument-for-the-vlir.pdf. Accessed January 27, 2016.

113. Pollack A. Opting against Ebola drug for ill African doctor. The New York Times. August 12, 2014. Available from: http://www.nytimes. com/2014/08/13/world/africa/ebola.html?_r=0. Accessed January 27, 2016.

114. The Henry J Kaiser Family Foundation. U.S. Federal Funding for HIV/AIDS: The President's FY 2016 Budget Request. April 13, 2015. Available from: http://kff.org/global-health-policy/fact-sheet/u-sfederal-funding-for-hivaids-the-presidents-fy-2016-budget-request/. Accessed January 27, 2016.

115. Benatar SR, Daar AS, Singer PA. Global health ethics: the rationale for mutual caring. Int Affairs. 2003;79(1):107-138.
Risk Management and Healthcare Policy

\section{Publish your work in this journal}

Risk Management and Healthcare Policy is an international, peer-reviewed open access journal focusing on all aspects of public health, policy, and preventative measures to promote good health and improve morbidity and mortality in the population. The journal welcomes submitted papers covering original research, basic science, clinical and epidemiological

\section{Dovepress}

studies, reviews and evaluations, guidelines, expert opinion and commentary, case reports and extended reports. The manuscript management system is completely online and includes a very quick and fair peerreview system, which is all easy to use. Visit http://www.dovepress.com/ testimonials.php to read real quotes from published authors. 